\title{
Pengelolaan Desa Wisata Berbasis Masyarakat di Desa Mas, Ubud
}

Haniva Rohmatul Jannah a,1 Ida Ayu Suryasih a,2

1hanivarohma26@gmail.com, 2idaayusuryasih@unud.ac.id

a Program Studi Sarjana Destinasi Pariwisata, Fakultas Pariwisata, Universitas Udayana, Jl. Dr. R. Goris, Denpasar, Bali 80232 Indonesia

\section{Abstract}

This research aims to obtain a clear description, complete and in-depth about the management of the tourist village in Mas Village, Ubud as well as to know the community participation in management of tourist village.

Research method that used in this research is descriptive qualitative. Data collection is done by observation, interview, literature study and documentation. Data analysis technique that used is descriptive qualitative analysis technique, such as data collection, data reduction, similar data grouping and data interpretation.

The results showed that in the management of Mas Tourism Village can be seen: (1) in the planning aspect type of participation is induced participation; (2) in the organizing aspect type of participation is induced participation; (3) in the actuating aspect type of participation is spontaneous participation; (4) in the controlling aspect type of participation is induced participation. Community participation in the management descripted on three indicators, namely (1) decision making that can be seen on organizing, actuating and controlling, (2) implementation of management that can be seen on planning, organizing, actuating and controlling, (3) sharing profit that can be seen on organizing.

Key word: management, community participation, tourist village

\section{PENDAHULUAN}

Desa wisata menjadi salah satu program yang digunakan untuk menggali potensi desa yang dikelola sebagai daya tarik wisata. Desa wisata dapat diartikan bahwa di desa tersebut terdapat suatu daya tarik dan karakteristiknya yang membedakan dari desa lain baik dalam hal sumber daya alam maupun seni dan budaya, bahkan kegiatan sosial masyarakat didalamnya. Yang mana kemudian dikelolanya potensi tersebut dilengkapi dengan fasilitas, sarana dan prasarana yang menunjang kegiatan pariwisata. Dengan begitu suatu desa yang dicanangkan sebagai desa wisata memiliki peluang dan daya jual terhadap wisatawan untuk menikmati daya tarik wisata yang ada, memperoleh pengalaman, berbagi pengetahuan, dan mendapatkan kenangan yang mengesankan. Akan tetapi, aspek pengembangan desa wisata yang tidak terlepas dari keterlibatan masyarakat menjadi tantangan tersendiri. Pasalnya, tidak mudah mengajak masyarakat lokal untuk berkecimpung dalam dunia pariwisata yang jauh berbeda dengan apa yang mereka kerjakan sebelumnya. Oleh sebab itu, perlu dilakukan pendekatan-pendekatan kepada masyarakat lokal agar mereka paham dan mengerti bagaimana jalannya kegiatan pariwisata serta bagaimana pelaksanaan desa wisata itu sendiri.
Berbicara mengenai keterlibatan masyarakat lokal dalam pariwisata yang kemudian dari hal tersebut tercipta sebuah istilah pariwisata berbasis masyarakat, atau yang dikenal dengan Community Based Tourism (CBT). CBT bukan suatu industri pariwisata yang memiliki tujuan sederhana yaitu untuk memaksimalkan perolehan manfaat ekonomi. Meskipun hal tersebut juga menjadi prioritas dalam pengembangan CBT, namun lebih dari itu adalah untuk terkonsentrasi pada dampak yang dihasilkan industri pariwisata terhadap komunitas dan lingkungannya. Melalui CBT atau pariwisata berbasis masyarakat, komunitas lokal diharapkan dapat berpartisipasi dalam pembangunan dan pengembangan kepariwisataan di daerah masing-masing dan memberikan perhatian lebih terhadap sumber daya alam, seni, dan budaya yang mereka miliki disamping meningkatkan kesejahteraan sosial melalui manfaat ekonomi yang diperoleh. Desa Mas telah lama menjadi desa wisata, yang mana dalam pengembangan desa wisata terdapat hal-hal yang harus diperhatikan sehingga nantinya dapat meminimalkan dampak pariwisata yang bersifat destruktif. Salah satunya adalah dengan memperhatikan aspek keterlibatan masyarakat, yang mana masyarakat menjadi objek dan subjek dalam pengelolaan desa wisata dengan segala upaya 
pengembangannya. Masyarakat harus benarbenar paham atas apa yang sedang dikembangkan di desa tersebut. sehingga, masyarakat sebagai pemilik modal sumber daya pariwisata dapat berpartisipasi aktif dalam pemilihan keputusan dan pembagian hasil.

Akan tetapi, masyarakat di Desa Mas tidak semuanya mengerti seperti apakah seluk beluk desa wisata itu sendiri. Apa tujuan dikembangkannya hingga bagaimana tata cara pelaksanaannya. Hal ini tentunya akan mempengaruhi partisipasi mereka dalam pengelolaan Desa Wisata Mas. Oleh sebab itu, hal menarik untuk diteliti mengenai partisipasi yang tidak hanya sekedar seberapa besar mereka dapat menjual produk kerajinan tangan yang mereka buat, namun lebih dari itu, seberapa besar masyarakat lokal ikut berkecimpung dalam perencanaan, pelaksanaan, penggerakan hingga evaluasi pengelolaan desa wisatanya. Sehingga nanti, tidak hanya sekedar manfaat ekonomi yang didapat, namun juga pelestarian alam, serta pelindungan atas aset budaya yang mereka miliki.

\section{TINJAUAN PUSTAKA \\ 2.1 Desa Wisata}

Desa wisata dapat dipahami dengan pengertian bahwa di desa itu dapat terjadi kegiatan pariwisata karena adanya daya tarik kehidupan desa dengan karakteristik yang terdapat di dalamnya, termasuk masyarakat yang ada di desa itu (Purwanggono, 2017). Apabila suatu desa dicanangkan sebagai desa wisata, maka hal yang harus diperhatikan adalah potensi desa yang akan dikembangkan sebagai daya tarik wisata, penyediaan fasilitas, sarana dan prasarana penunjang kegiatan pariwisata, serta sumber daya manusia penyedia jasa dalam kegiatan pariwisata, yang dalam hal ini adalah masyarakat setempat. Purwanggono (2017) juga menuturkan tentang pentingnya penerimaan, kesediaan, atau kesanggupan partisipasi masyarakat terhadap kegiatan pariwisata yang akan diselenggarakan di desa dimana masyarakat itu tinggal.

\subsection{Pengelolaan}

Menurut G.R. Terry, dalam pengelolaan terdapat empat fungsi dasar, antara lain Planning (Perencanaan), Organizing
(Pengorganisasian), Actuating (Pelaksanaan) dan Controlling (Pengawasan). Keempat fungsi manajemen ini disingkat dengan POAC.

\section{Planning (Perencanaan)}

Perencanaan sebagai dasar pemikiran dari tujuan dan penyusunan langkah-langkah yang akan dipakai untuk mencapai tujuan. Merencanakan berarti mempersiapkan segala kebutuhan termasuk didalamnya strategi, kebijaksanaan, proyek, program, prosedur, anggaran, dan standar yang dibutuhkan, memperhitungkan matang-matang apa saja yang menjadi kendala, dan merumuskan bentuk pelaksanaan kegiatan yang bermaksud untuk mencapai tujuan.

2. Organization (Pengorganisasian)

Pengorganisasian ialah penentuan, pengelompokkan, dan penyusunan macammacam kegiatan yang diperlukan untuk mencapai tujuan, penempatan orang-orang (pegawai), penyediaan faktor-faktor fisik yang cocok bagi keperluan kerja dan penunjukkan hubungan wewenang, yang dilimpahkan terhadap setiap orang dalam hubungannya dengan pelaksanaan setiap kegiatan yang diharapkan.

3. Actuating (Penggerakan)

Penggerakan adalah untuk menggerakan organisasi agar berjalan sesuai dengan pembagian kerja masing-masing serta menggerakan seluruh sumber daya yang ada dalam organisasi agar pekerjaan atau kegiatan yang dilakukan bisa berjalan sesuai rencana dan bisa mencapai tujuan.

4. Controlling (Pengawasan)

Pengawasan dapat dirumuskan sebagai proses penentuan apa yang harus dicapai yaitu standard, apa yang sedang dilakukan yaitu pelaksanaan, menilai pelaksanaan, dan bilamana perlu melakukan perbaikanperbaikan, sehingga pelaksanaan sesuai dengan rencana, yaitu selaras dengan standar (ukuran).

\subsection{Partisipasi Masyarakat}

Tipologi partisipasi menurut Tosun yang didesain khusus untuk mengkaji partisipasi masyarakat dalam sektor pariwisata karena mengelaborasikan setiap tipe partisipasi masayarakatnya dengan referensi khusus terkait industri pariwisata. Dalam tipologi partisipasi tersebut, Tosun membagi bentuk 
partisipasi masyarakat kedalam tiga tipe, yaitu sebagai berikut:
1. Partisipasi
Paksaan
(Coercive Participation)
2. Partisipasi
Terdorong
(Induced
3. Partisipasi Spontan Participation)
(Spontaneous

III. HASIL DAN PEMBAHASAN

\subsection{Implikasi Terhadap Usaha Akomodasi}

Daya Tarik Wisata Bahari Tulamben memiliki beragam bentuk usaha akomodasi mulai dari homestay, resort, vila, hingga hotel. Berdasarkan pengamatan dan wawancara yang telah dilakukan bahwa pasca erupsi Gunung Agung memiliki pengaruh yang cukup besar terhadap usaha akomodasi

Perubahan operasional pada usaha akomodasi pasca erupsi Gunung Agung yaitu menerapkan sistem jam kerja tidak tetap. Dalam kondisi normal usaha akomodasi pariwisata di Daya Tarik Wisata Bahari Tulamben jam operasional staff dan pegawai adalah 8 jam dengan menerapkan sistem shift dengan mengelola pembagian jobdesk karyawan menjadi tiga shift yaitu pagi, siang dan malam.

Perubahan operasional memiliki keterkaitan dengan pendapatan (tingkat hunian) terhadap usaha akomodasi. Pengusaha perusahaan usaha jasa hingga memberikan potongan harga 30 persen untuk wisatawan. Penurunan okupansi tersebut menyebabkan pengusaha tidak dapat membayar kompensasi (gaji) kepada karyawan secara penuh (full).

Secara tidak sadar penurunan okupansi bersinggungan dengan etos kerja dan pudarnya semangat kerja karyawan di suatu usaha akomodasi di Daya Tarik Wisata Bahari Tulamben hingga menyebabkan karyawan memutuskan untuk mengundurkan diri dan kehilangan pekerjaan.

Upaya yang telah dilakukan pihak pengusaha usaha akomodasi di Daya Tarik Wisata Bahari seperti pemaparan di atas dalah dengan terus melakukan promosi dengan memberikan pemotongan harga untuk wisatawan yang akan menginap. Jika kunjungan wisatawan sudah normal tentu akan memulihkan krisis yang timbul seperti operasional usaha akomodasi akan kembali normal, okupansi perusahaan akan meningkat dengan perlahan, serta semangat kerja karyawan akan timbul kembali.

\subsection{Implikasi terhadap Usaha Diving dan Snorkeling}

Pantai Tulamben pasca erupsi Gunung Agung yang sangat tidak kondusif, wisatawan panik dan merasa tidak aman saat melakukan aktivitas penyelaman. Pasca erupsi Gunung Agung usaha diving dan snorkeling di Daya Tarik Wisata Bahari Tulamben merasakan dampak yang sangat memiliki keterkaitan besar terhadap perekonomian mereka seperti perubahan operasional dan penurunan pendapatan. Dahulu, operasional jam kerja penuh bahkan hingga malam hari karena ada permintaan dari wisatawan namun ketika aktivitas Gunung Agung semakin meningkat yang berberimplikasi terhadap jumlah kunjungan wisatawan yang menurun setiap harinya menyebabkan aktivitas diving dan snorkeling tidak optimal seperti kondisi normal. Jumlah kunjungan wisatawan yang menurun memiliki efek kepada pendapatan pemandu diving di Daya Tarik Wisata Bahari Tulamben. Pemandu diving hanya melakukan profesinya saat ada permintaan atau request dari wisatawan.

Permasalahan lainnya yang timbul yaitu adanya perpindahan tangan kepemilikan usaha diving dan snorkeling milik masyarakat lokal menjadi milik investor asing. Masyarakat lokal menjual usaha diving dan snorkeling ke investor asing karena tak mampu untuk membayar perawatan fasilitas untuk penyelaman dan memenuhi kebutuhan karyawan seperti memberikan kompensasi. Hal tersebut merupakan dampak langsung erupsi Gunung Agung pada usaha jasa pariwisata yang sangat besar karena masyarakat lokal telah menjual usaha yang dimiliki kepada investor asing.

Upaya-upaya yang telah dilakukan pengusaha usaha jasa diving dan snorkeling pasca erupsi Gunung Agung di Daya Tarik Wisata Bahari Tulamben yaitu dengan hanya 
menggandalkan promosi dari media sosial dan mengajak kembali wisatawan repeater untuk berkunjung kembali.

\subsection{Implikasi terhadap Tenaga Porter}

Usaha diving dan tenaga porter memiliki hubungan profesi yang terkait yaitu porter sebagai suatu jasa dalam pengangkutan alatalat selam. Pasca erupsi Gunung Agung di Daya Tarik Wisata Bahari Tulamben yang memiliki atraksi utama penyelaman ke drop off Pantai Tulamben untuk melihat biota laut, berkaitan secara langsung terhadap porter. Seorang porter pada kondisi normal dapat mengangkut minimal 30 set alat selam perhari namun dengan adanya aktivitas Gunung Agung menyebabkan seorang porter hanya bisa mengangkut minimal 10 set alat selam perhari karena jumlah kunjungan wisatawan yang melakukan aktivitas penyelaman sedikit. Upaya yang dilakukan oleh pengelola jasa porter adalah hanya tetap menunggu panggilan dari usaha diving atau snorkeling terkait permintaan aktivitas.

\subsection{Implikasi terhadap Usaha Makanan dan Minnuman}

Usaha Jasa Makanan dan Minuman yang terdapat di Daya Tarik Wisata Bahari Tulamben tidak luput dari implikasi pasca erupsi Gunung Agung. Berdasarkan pengamatan yang dilakukan di sekitar Pantai Tulamben terdapat jejeran restoran yang sepi dan tidak ada pengunjung yang menyebabkan penurunan penerimaan (gaji) dan perubahan operasional restoran dan tempat makan. Upaya yang dilakukan adalah hanya tetap membuka restoran walaupun kunjungan wisatawan tidak seperti dahulu.

\subsection{Matriks Implikasi Erupsi Gunung Agung terhadap Usaha Pariwisata}

Matrik implikasi erupsi Gunung Agung terhadap usaha pariwisata dapat dilihat pada Tabel 1.

Tabel 1.

Matriks Implikasi Erupsi Terhadap Usaha

Pariwisata di Daya Tarik Wisata Bahari

Tulamben

\begin{tabular}{|l|l|l|l|} 
No & Usaha & Implikasi & Upaya \\
\hline
\end{tabular}

\begin{tabular}{|c|c|c|c|}
\hline & Pariwisata & & Penyelesaian \\
\hline 1 & $\begin{array}{l}\text { Usaha } \\
\text { Akomodasi }\end{array}$ & $\begin{array}{l}\text { perubahan } \\
\text { operasional, } \\
\text { penurunan } \\
\text { okupansi dan } \\
\text { kehilangan } \\
\text { Pekerjaan }\end{array}$ & $\begin{array}{l}\text { Promosi } \\
\text { menggunakan } \\
\text { sosial media } \\
\text { dengan } \\
\text { memberikan } \\
\text { potongan } \\
\text { harga }\end{array}$ \\
\hline 2 & $\begin{array}{l}\text { Usaha } \\
\text { Diving dan } \\
\text { Snorkeling }\end{array}$ & $\begin{array}{l}\text { Perubahan } \\
\text { operasional dan } \\
\text { penurunan } \\
\text { okupansi }\end{array}$ & $\begin{array}{l}\text { Promosi } \\
\text { menggunakan } \\
\text { sosial media }\end{array}$ \\
\hline 3 & $\begin{array}{l}\text { Usaha Jasa } \\
\text { Porter }\end{array}$ & $\begin{array}{l}\text { Kehilangan } \\
\text { pekerjaan }\end{array}$ & - \\
\hline 4 & $\begin{array}{l}\text { Usaha } \\
\text { Makan dan } \\
\text { Minum }\end{array}$ & $\begin{array}{l}\text { Perubahan } \\
\text { operasional dan } \\
\text { penurunan } \\
\text { pendapatam }\end{array}$ & Tetap buka \\
\hline
\end{tabular}

Sumber: Penelitian Lapangan III, 2018

\section{IV.PENUTUP}

Daya Tarik Wisata Bahari Tulamben memiliki usaha pariwisata seperti perusahaan akomodasi, bisnis diving dan snorkeling, tenaga porter, dan usaha jasa makan dan minum. Namun, pasca erupsi Gunung Agung memiliki pengaruh secara langsung terhadap usaha pariwisata yang terdapat di Daya Tarik Wisata Bahari Tulamben seperti perubahan operasional, pengurangan pendapatan, dan kehilangan pekerjaan.

Rekomendasi yang diberikan kepada pemerintah dengan memberikan penyuluhan terkait kewaspadaan bencana alam, menyusun media branding replacement untuk pemulihan, menjadi fasilitator dalam promosi dan kerjasama nasional dan kerjasama internasional. Pengusaha pariwisata diharapkan keamanan wisatawan selama berkunjung dengan memberikan penawaran-penawaran menarik untuk wisatawan untuk meningkatkan jumlah kunjungan, memberikan pengertian untuk wisatawan terkait kenyamanan dan keamanan saat melalukan aktivitas pariwisata di Daya Tarik Wisata Tulamben. Masyarakat Lokal disarankan untuk mampu menggali potensi wisata yang terdapat di Daya Tarik Wisata Bahari Tulamben dengan menciptakan atraksi wisata yang baru dengan melibatkan penduduk setempat dan tidak mudah mengikuti arahan investor asing 
untuk menjual usaha atau sumber daya yang dimiliki.

\section{DAFTAR PUSTAKA}

Anomim. 2009. Undang-Undang Republik Indonesia No. 10 Tahun 2009. Tentang Kepariwisataan. Jakarta

Dinas Kebudayaan dan Pariwisata Kabupaten Karangasem. 2013. Data Kepariwisataan Kabupaten Karangasem. Amlapura

Echols, M. John dan Shadily Hasan, 1989. Kamus Indonesia - Inggris, Jakarta : Gramedia Pustaka Utama.

Febriaty, Hastina. 2015 "Dampak Erupsi Gunung Sinabung terhadap Pendapatan dari Sektor Pariwisata di Kabupaten Karo." Jurnal Ekonomikawan

Muljadi, A.J, Kepariwisataan dan Perjalanan. Jakarta: Raja Grafindo Persada
Suardana, Wayan I dan Susrami Dewi IGA. 2015. "Dampak Pariwisata terhadap Mata Pencaharian Masyarakat Pesisir Karangasem: Pendekatan Pro Poor Tourism." PIRAMIDA.

Suastika, Nyoman. 2017. Matinya Tulamben akibat Krisis Gunung Agung [Online] dalam https://balebengong.id/berita-utama/akibatkrisis-gunung-agung.html?lang=id diakses pada Rabu, 28 Februari 2018 pukul 19.00 WITA

Subhan, B. 2014 Kehidupan Laut Tropis Tulamben. Bogor: IPB Press

Sugiarti,Rini (2012). Managemen Krisis Candi Borobudur (Studi Desktiptif Kualitatif pada PT. Taman Wisata Candi Borobudur, Prambanan, dam Ratu Boko dalan Pelestarian World Heritage Pasca Erupsi Merapi. Yogyakarta: UIN Sunan Kalijaga 